\title{
EFFECT OF ANTICOAGULANT DRUGS IN REDUCING THE RISK OF MORTALITY IN COVID-19 PATIENTS: A META-ANALYSIS
}

\author{
Happy Nurhayati \\ Masters Program in Public Health, Universitas Sebelas Maret
}

\begin{abstract}
Background: COVID-19 is widely continue to spread worldwide. Deaths among people with COVID-19 have been partially attributed to venous thromboembolism and arterial thromboses. Several expert organizations have recommended prophylactic anticoagulation for patients admitted with covid-19, who do not have a contraindication to this treatment, to reduce the risk of thromboembolism. However, results from different studies comparing the effect of anticoagulation on the mortality of COVID-19 patients with non-anticoagulation are inconclusive. A systematic review and metaanalysis was conducted to assess the effect of anticoagulant drugs in reducing the risk of mortality in COVID-19 patients.

Subjects and Method: A systematic review was conducted using the Pub $\neg$ Med, Science direct, Scopus databases, published from 2020 to 2021. Eligibility criteria were defined using the PICO model as follows, (1) population: COVID-19 patients, (2) intervention: coagulant drugs, (3) comparison: non-coagulant drugs, and (4) outcome: mortality. The following search terms were used: "anticoagulant" AND "mortality" AND "COVID-19". The inclusion criteria were English full-text, cohort retrospective study, and reported adjusted Odds Ratio (aOR). Data analyses were performed using REVMAN 5.3.

Results: Six studies were selected from Kuwait, German, Italy, China, and Spain. This study showed that coagulant drugs reduced the risk of mortality in COVID-19 patients, but it was statistically non-significant $(\mathrm{OR}=0.51 ; 95 \% \mathrm{CI}=0.39$ to $0.66 ; \mathrm{p}=0.160)$.

Conclusion: Coagulant drugs reduces the risk of mortality in COVID-19 patients.
\end{abstract}

Keywords: Anticoagulant, mortality, COVID-19

\section{Correspondence:}

Happy Nurhayati. Masters Program in Public Health, Universitas Sebelas Maret. Jl. Ir. Sutami 36A, Surakarta 57126, Central Java. Email: happynurhayati@student.uns.ac.id. Mobile: +62812-2616-0538. 